Process-based indicators to assess storm induced coastal hazards

Óscar Ferreira, Theocharis A. Plomaritis, Susana Costas

CIMA/FCT, University of Algarve, Campus de Gambelas, 8005-139, Faro, Portugal;

oferreir/tplomaritis/scotero@ualg.pt

Corresponding author: Óscar Ferreira (oferreir@ualg.pt)

\title{
Abstract
}

Storms are responsible for several hazards (e.g. overwash, erosion, inundation) in coastal areas, leading to the destruction of property and loss of life in populated areas. Various indicators are used to express potential storm impact and describe the associated hazards. The most commonly used indicators include either forcing parameters (e.g. wave height, sea level) or coastal morphologies (e.g. dune height or berm width). Whereas they do not represent the processes associated with storm induced hazards in coastal areas. Alternatively, a hazard could be better characterised if process-based indicators are used instead. Process-based indicators express the result of the forcing mechanisms acting over the coastal morphology and reflect both hydrodynamic and morphological characteristics. This work discusses and synthesizes the most relevant process-based indicators for sandy shores subject to overwash, erosion and inundation promoted by storms. Those include: overwash depth, potential and extent; shoreline, berm or dune retreat; vertical erosion; and inundation depth and extent. The selection of a reduced set of process-based indicators to identify coastal hazards induced by storms in sandy coasts will facilitate comparison of different coastal behaviours for distinct storm return periods, and help to optimise coastal management plans, thereby contributing to the reduction of coastal risks. 


\section{Process-based indicators to assess storm induced}

\section{2 coastal hazards on sandy coasts}

3 Óscar Ferreira, Theocharis A. Plomaritis, Susana Costas

4 CIMA/FCT, University of Algarve, Campus de Gambelas, 8005-139, Faro, Portugal;

5 oferreir/tplomaritis/scotero@ualg.pt

6 Corresponding author: Óscar Ferreira (oferreir@ualg.pt)

7

8 Abstract

9 Storms are responsible for several hazards (e.g. overwash, erosion, inundation) in 10 coastal areas, leading to the destruction of property and loss of life in populated areas.

11 Various indicators are used to express potential storm impact and describe the 12 associated hazards. The most commonly used indicators include either forcing 13 parameters (e.g. wave height, sea level) or coastal morphologies (e.g. dune height or 14 berm width). Whereas they do not represent the processes associated with storm 15 induced hazards in coastal areas. Alternatively, a hazard could be better characterised 16 if process-based indicators are used instead. Process-based indicators express the 17 result of the forcing mechanisms acting over the coastal morphology and reflect both hydrodynamic and morphological characteristics. This work discusses and synthesizes the most relevant process-based indicators for sandy shores subject to overwash, erosion and inundation promoted by storms. Those include: overwash depth, potential and extent; shoreline, berm or dune retreat; vertical erosion; and inundation depth 
and extent. The selection of a reduced set of process-based indicators to identify coastal hazards induced by storms in sandy coasts will facilitate comparison of different coastal behaviours for distinct storm return periods, and help to optimise coastal management plans, thereby contributing to the reduction of coastal risks.

Keywords: indicators; hazards; storms; overwash; inundation; erosion

\section{Introduction}

Storms impacting sandy coastal areas produce hazards such as erosion and inundation that, in turn, promote risk to life and property damage in occupied areas, and the alteration and/or fragmentation of habitats. Recent examples include the severe coastal erosion and associated destruction of property caused by Hercules storm (January 2014) that impacted the southwest coasts of France and England (Castelle et al., 2015; Masselink et al., 2016a,b); the inundation and loss of life caused by the Xynthia storm (February/March 2010) in western France (e.g. Bertin et al., 2012); the vast destruction caused by the superstorm Sandy (October/November 2012), in the coastal mid-Atlantic states of the USA (Bennington and Farmer, 2015; Clay et al., 2016), or by hurricane Katrina (August 2005), at the Golf coast of the USA (Link, 2010; Kantha, 2013). Potential coastal damages and risks are expected to increase in the near future not only in association with climate change (e.g. sea level rise, change in frequency and magnitude of storms) but also due to increasing human occupation in coastal areas (Neumann et al., 2015). 
44 Indicators, as a metric for coastal state, dynamics, behaviour or hazard, are a straightforward way to express complex data and information and can therefore be an important tool in the dialog among stakeholders (Carapuço et al., 2016). They are often based on a parameter that is used to characterise a coastal area. Coastal hazard indicators are commonly used to express the potential storm impacts in coastal areas, helping to identify and prioritise vulnerable regions (Nguyen et al., 2016). Storm related hazards have been expressed in the literature by a large number of different indicators that have been recently synthesised by the review works of Carapuço et al. (2016) and Nguyen et al. (2016). For coastal erosion and flooding hazards Carapuço et al. (2016) identified (and recommended) the use of several geoindicators, like shoreline/baseline position, shoreline evolution, beach/barrier elevation or beach slope. Nguyen et al. (2016) synthesized the existing indicators in literature related to storm surge-driven flooding and coastal vulnerability and included geoindicators (e.g. coastal slope, geomorphologic characteristics), hydrodynamic indicators (e.g. wave height, tidal range, surge height) and coastal evolution indicators (e.g. erosion rate, shoreline/coastline position). The aforementioned indicators, which represent a summary of the ones that have been widely used and referred to in the international literature, include forcing/driver parameters, coastal morphology characteristics and even coastal evolution. It is, however, not clear how to select the most representative parameter for a given hazard. The most commonly used parameters describe either the driving mechanisms or the coastal morphology, rarely integrating both or fully representing the processes associated with storm induced hazards in coastal areas. 
67 and/or values that are averaged over time, which can cause difficulties (and

68 exaggerated simplicity) in their application.

69 To fully characterise a coastal hazard it is necessary to use a set of indicators that 70 combines the forcing mechanism and its effect on the coastal morphology, i.e. 71 process-based indicators. The majority of the indicators found in the literature cannot 72 be considered process-based. Process-based indicators can only be obtained from the 73 application of models that incorporate physical forcing mechanisms and that include 74 realistic coastal morphology elements, resulting in a parameter or set of parameters 75 that express the effects of the processes acting on the coastal system.

76 This work reviews and synthesizes the most relevant process-based coastal indicators 77 that can be applied for sandy coasts subject to storm-induced coastal hazards. The 78 main hazards assessed are: overwash, inundation, and erosion. The main goal is to propose a set of process-based indicators that can serve as a reference for coastal

80 hazard studies on sandy shores. The rationale for using process-based indicators is 81 described in section 2. The definition, discussion and selection of indicators for each

82 analysed coastal hazard are detailed in section 3. Section 4 provides a synthesis of the 83 proposed indicators and their applicability, based on the use of simple parameters

84 highly representative of coastal hazards. Final considerations on current limitations and future use of process-based indicators at sandy coasts are discussed in section 5.

2. Process-based indicators 
The vast majority of recommended coastal hazard related indicators in the literature (see reviews by Bush et al., 1999; Carapuço et al., 2016; Nguyen et al., 2016) only take into account: (i) the characteristics of the physical/morphological features of the coastal system, or (ii) the driving mechanism. Combinations between both, representing the processes and the consequent hydrodynamic or morphological results (process-based indicators), are not commonly used and have not yet been the subject of a synthesis. Process-based indicators are directly related to hazard and represent the interaction between driving mechanisms and the coastal morphology. The process-based indicators are therefore obtained by using formulations or models (from simple to complex) that will combine the driving mechanisms (e.g. storm parameters like wave height, wave period, storm duration or sea level) and the coastal system morphology (such as beach face slope, dune height, berm width, grain size or bathymetry) (Figure 1, steps 1 and 2). The result will be an impact (e.g. erosion, overwash occurrence) that can be expressed through an indicator that has a physical meaning (e.g. flood depth, shoreline retreat). Overall, results can be reclassified into new classes that express different levels of hazard according to stipulated limits/thresholds allowing an illustrative mapping of the hazard (Figure 1, steps 3 and 4). These thresholds can be defined locally or regionally, allowing a comparison of the hazard intensity within a specific coastal area and also between different coastal areas. Furthermore, such indicators can often be used to estimate (or to indicate) the extent of the hazards, allowing the representation of the spatial distribution of the coastal hazard. However, it is worth mentioning that the thresholds depend on the hazard receptor-type (e.g. dunes, salt marsh, houses, infrastructure), defined according to the Language of Risk (Gouldby and Samuels, 2005) and, therefore, comparisons should be 
112 restricted to similar receptors. These indicators are comparable in concept to the

113 Coastal State Indicators (CSI), introduced by van Koningsveld et al (2005). CSI are

114 defined as "issue-related parameters that can simply, adequately and quantitatively

115 describe the dynamic-state and evolutionary trends of a coastal system" (Davidson et

116 al., 2006, 2007). The use of process-based indicators can therefore include alongshore

117 and cross-shore variability as well as time-dependency (e.g. inclusion of time-scales or

118 return periods). The indicators must, however, remain simple on application and

119 expression to ensure their applicability by most coastal managers. Examples of

120 commonly used process-based indicators (e.g. Wright and Short, 1984 or Masselink

121 and Hegge, 1995) include beach morphodynamic state indicators such as the surf

122 scaling parameter (Guza and Inman, 1975) and the surf similarity parameter (Battjes,

123 1974). However, these are not commonly applied to indicate the degree of coastal hazard.

124 In fact, widely accepted process-based indicators to represent storm hazard at sandy coasts have not yet been defined and used.

STEP 1

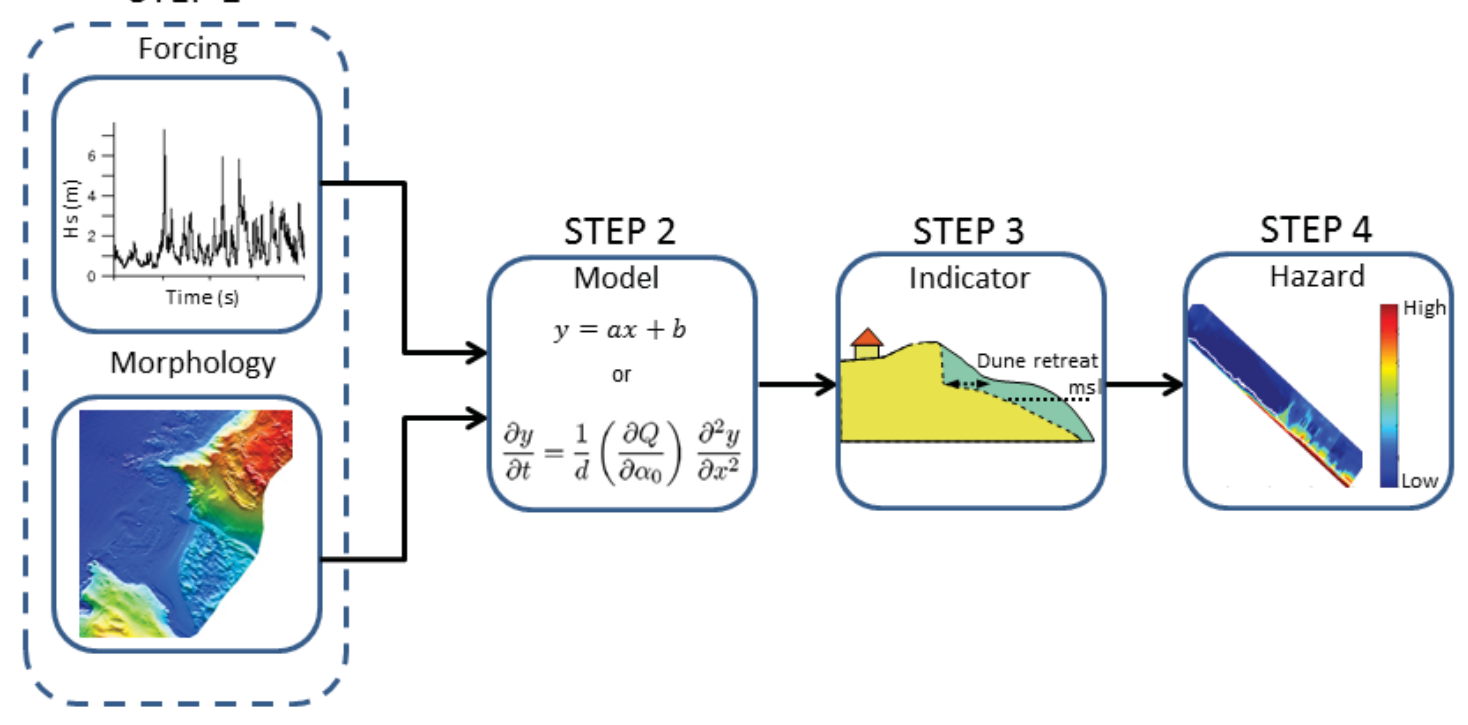


Figure 1. Scheme representing the steps needed to obtain a process-based indicator, and its use for hazard assessment. Driving mechanisms and coastal morphology (Step 1) are integrated in numerical models (from simple to complex) to produce a processprobability distribution. This method is particularly recommended when the forcing based indicator (step 3) that can be used to express the hazard degree (step 4).

Two possible approaches can be used to obtain the indicator's variability through time: event approach and response approach (see Divory and McDougal, 2006; Bosom and Jiménez, 2011; Ferreira et al., 2016). The event approach, also called deterministic, uses the extreme probability distribution of the physical forcing parameter and the present day coastal morphology (or any simulated condition) to determine the process-based indicator. The storm parameter (e.g. wave height) for a given return period is obtained from the corresponding extreme distribution. A formulation/model (Step 2 on Figure 1) is then applied for the dominant (or other) morphological condition and the process-based indicator is obtained (e.g. overwash depth, shoreline retreat) for that return period. In this approach the obtained indicator is then associated with one value of a storm parameter, for a given return period, losing significant information on the natural variability of the process (Sánchez-Arcilla et al., 2009). The response approach, also called the probabilistic approach, uses the entire forcing parameter time-series (e.g. water level, wave height, storm duration) to obtain the indicators for all known conditions (e.g. runup, erosion) through time. A probability distribution of extremes must be fitted to the obtained indicator time-series and the indicator associated with a given return period will be computed from its own variables are poorly correlated or statistically independent (Bosom and Jiménez, 2011). 

morphodynamic and hydrodynamic state of sedimentary coasts, in support of coastal zone management (Davidson et al., 2006).

The indicators analysed in this paper are process-based and therefore describe the

A large number of the indicators that are currently used are frequently poorly defined (Carapuço et al., 2016). The existing lack of standardization of concepts and assumptions restricts the comparability between indicators and among different coastal areas (Nguyen et al., 2016). The use of different indicators may even result in significantly different hazard estimates, requiring greater caution in the selection of the appropriate indicators (Hanslow, 2007). All above expressed shortcomings call for a standardized approach, with clear guidelines for the determination and applicability of hazard indicators. Indicators should, therefore, be as simple as possible, unambiguous, reproducible in different coastal regions, and based on a consistent methodology that enables comparison between sites (see Carapuço et al., 2016; Nguyen et al., 2016). Moreover, they should be suitable for defining the dynamic interaction between the coastal morphological states and the driving mechanisms of the particular hazard. The computation of the proposed indicators for existing (or hindcast) data time-series, and subsequent probabilistic analysis of the indicators' distribution, will allow their use in association with return periods. Since the selected indicators are applicable to sandy coastal areas and can be associated with a given probability of occurrence, they allow direct comparisons or ranking of the hazard intensity between different coastal areas. For each indicator a set of thresholds can be 
established (at local, regional or international level) that can be used to classify and rank the hazard. Those limits will not be the subject of detailed analysis in this paper,

175 although application examples will be mentioned after the physical description of each 176 indicator.

Overwash indicators

Overwash occurs when wave induced runup overtops the foredune ridge or the highest beach/barrier elevation if the dune is absent. Following Matias and Masselink 181 (2017) the overwash is a discontinuous flow of seawater and sediment over the dune/beach crest, which will propagate inland for a given extent (distance to the initial dune/beach crest position). The two main indicators reflecting overwash induced hazards are: overwash potential and overwash depth. Overwash potential is defined as the vertical difference (in meters) between the potential wave runup (along an imaginary extended beach/dune slope) and the dune/beach crest elevation (Matias et al., 2012, 2016; Figure 2). Overwash depth can be defined (adapted from Donnelly, 2008) as the water depth (in meters) at a point (dune crest or backbarrier) during an overwash event. Overwash depth decreases with the distance across the backbarrier until reaching a zero value at the maximum inland overwash extent (Figure 2). Computation of both indicators requires the use of empirical equations to predict the runup (e.g. Holman, 1986; Stockdon et al., 2006; see Matias et al., 2012 for a review on formulations) and a digital terrain model. For complex environments, such as partially engineered coastlines or areas with a complex geomorphological framework, processbased models should be used to determine such indicators. 
Both indicators (overwash potential and overwash depth) state a vertical difference

between a water level associated with the overwash and the terrain (Figure 2). The overwash potential is easier to use because of its computational simplicity since it compares the result of a runup formulation with the height of the dune/berm crest.

The overwash depth needs extra formulations to determine the effective water lens depth at the crest and its cross-shore variability (see Donnelly, 2008). However, the overwash depth has the advantage of being physically representative of the actual process as it can be applied not only at the dune/beach crest but also at the backbarrier up to the maximum extent of the overwash (Figure 2). The computation of the overwash depth can be performed using the formulations proposed in Donnelly (2008), relating the overwash depth with infiltration and the velocity of the overwash flux. However, this approach has not been calibrated for all grain-sizes and assumes a simplified morphology. Overwash depth values at the back of the dune can be estimated by using an exponential decay that varies according to infiltration and lateral expansion of the flow. This also allows the definition of a maximum overwash extent which represents the total cross-shore extension of the overwash and can be applied as an indicator of the area prone to be flooded (e.g. Garcia et al., 2010; Ferreira et al., 2016; Christie et al., 2017). The inclusion of processes like infiltration and lateral expansion increases the applicability of the method by providing free parameters that can be set to local conditions and used as calibration parameters. A more effective (but also more complex and computationally demanding) way to compute the overwash depth is to use 1D or 2D numerical models. Other potential indicator to state the overwash hazard (for expected damages) is the overwash velocity. This is currently obtained (with limited field validation) by using models and it is therefore of restricted 
application. Alternatively, the overwash velocity can be estimated as a function of the overwash depth at the dune crest, as determined by Donnelly (2008) and Matias et al. (2016).

Existing studies mostly use the overwash depth and the overwash potential to determine the possibility of overwash for a given event. Negative values of these indexes are associated with swash or collision states, according to the storm impact scale proposed by Sallenger (2000), while positive values imply overwash (e.g. Almeida et al., 2012; Rodrigues et al., 2012) or higher hazard levels such as inundation (e.g. Bosom and Jiménez, 2011). Several researchers have applied the overwash potential indicator in order to find a storm threshold for morphological changes (e.g. Stockdon et al., 2007; Almeida et al., 2012; Armaroli et al., 2012; Del Río et al., 2012; Haerens et al., 2012; Trifonova et al., 2012). The use of the overwash depth is still limited (e.g., Ferreira et al., 2016; Poelhekke et al., 2016; Valchev et al., 2016; Christie et al., 2017) since it is not directly obtained by the most commonly used formulas (e.g. Holman, 1986; Stockdon et al., 2006) and has been rarely measured in the field, leading to lack of validation. However, it has to be stated that overwash depth is a measurable value in the field in contrast with the overwash potential. For gravel barriers and laboratory conditions, such measurements have been obtained by Matias et al. (2011) as a result of the Bardex Project (Williams et al., 2009). Future application of the overwash depth and overwash potential values should be based on severity scales, to be developed at local, regional or even international levels, as a function of the potential hazard associated with each overwash level. Specific depth damage curves can then be obtained to assess the risk associated with overwash such as already exists for riverine floods. 


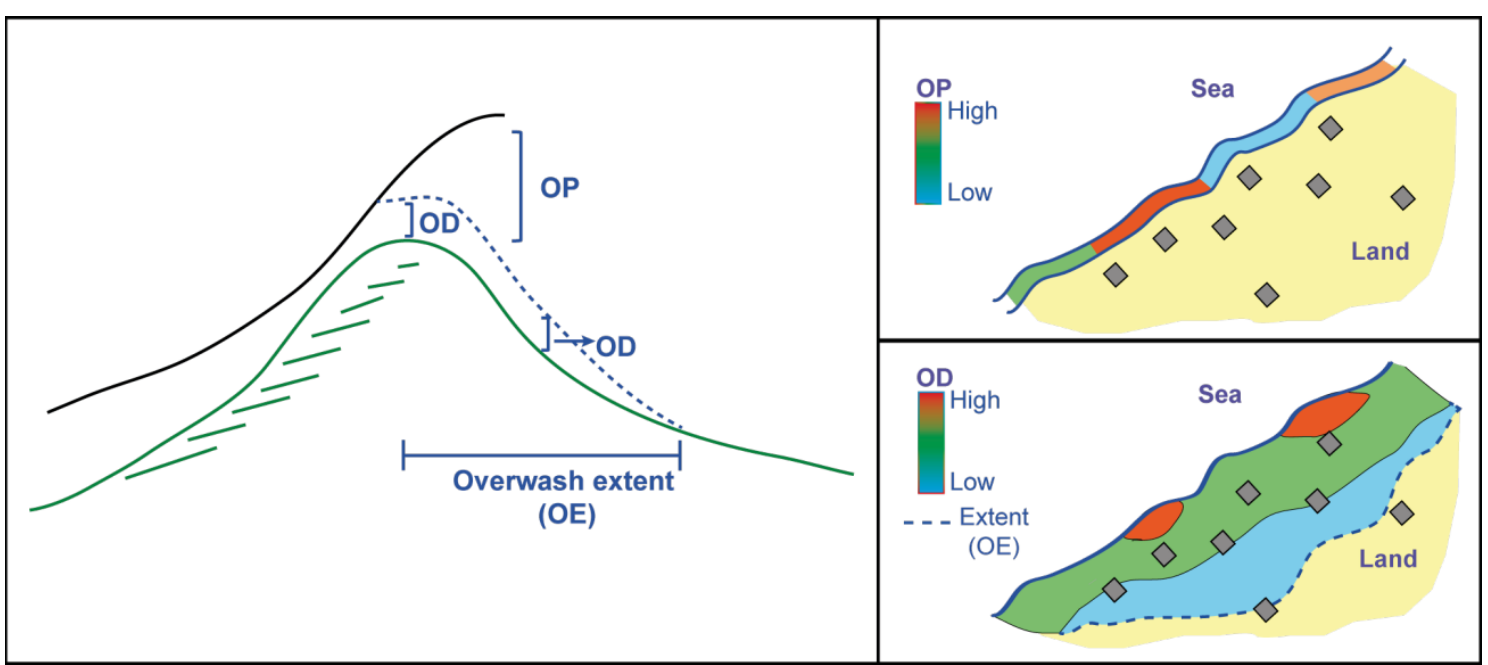

Fig 2. Cross-shore and plan view representing the concept and application of overwash

246 indicators. Grey squares represent the location of the hazard receptors (e.g. houses).

247 OD - overwash depth; OP - overwash potential; OE - overwash extent.

Inundation indicators

Inundation, which is here defined according to the concept proposed by Sallenger

251 (2000), occurs when the storm related still water level (tide + surge) is sufficient to

252 completely and continuously submerge a barrier (i.e. the dune crest or the highest

253 barrier elevation). Inundation should not be confused with overwash, were an

254 intermittent runup level overpasses the barrier for short periods (seconds), and must

255 be treated separately as different time (hours to days) and spatial (larger areas and

256 depths) scales are involved. Important processes for tide/surge interactions that can

257 affect the water level (surge height) are surge propagation during the tidal cycle and wind forcing. The continental shelf depth and width are important factors on the amplification (mainly for shallow and wide shelves) of both processes (see Fortunato et 
water level (Bertin et al., 2012). For small areas, the total water level can be assumed constant but when the inundation affects very large areas a variable level could be applied (Breilh, et al., 2014).

264 The extent of the inundation can be determined through several methods with different degrees of complexity. A simple bathtub model approach can be used for areas with low morphological complexity (Figure 3). In this method, a given area becomes inundated if its elevation is less than the water level (Poulter and Halpin, 2008) while a vertical water depth can be computed at each point. The method does not account for infiltration, roughness or shear stress and therefore it can lead to overestimation. An adaptation can be performed in order to reduce the level of error on the estimation of the inundated area and water depth by using a tilted water surface (Figure 3) along a sloping plane (see Sekovski et al., 2015) based on historical 273 information and cartography. Problems arise from the application of this simple methodology when the total inundated area is large and therefore the time needed to achieve complete inundation is too long when compared with the actual flooding time. This is particularly valid in inundation areas subjected to tides, where the inundation

277 level can occur for just a few hours. In such cases, more complex methods, such as the 278 flood intensity index (Dottori et al., 2016) should be applied. This index reproduces flooding processes using as theoretical background the 1D uniform flow equation, and considers the vertical differences between the water level at a given source of the flow and the elevation of the adjacent terrain. Inundation models, such as LISFLOOD (De Roo et al., 2000), which can account for lateral connectivity and permeability, can also be used to better represent the inundation area and depth. The main indicator to be used on hazard assessment should be the flood depth (see Figure 3) at each hinterland 
position, which expresses the intensity of the hazard and its variability along each considered coastal region. Other useful indicators worth of mentioning are the total

287 flood extent (see Figure 3) from a given reference point (e.g. the shoreline), and the percentage of flooded area per coastal sector (from the shoreline to a given previously defined hinterland limit). The overflowing discharge volume can also be used. This indicator is a function of the overflow depth at the crest of a dune or dyke multiplied by its length and integrated over time using the rectangular weir discharge equation of Kindsvater and Carter (1957). The extension of the overflowing discharge volume can be calculated by a step by step increase in the water level until the total volume is reached. Similarly, the volume can be used in combination with the tilting bathtub method to compare inundation volumes.

An example of the application of the tilted bathtub method can be found in Sekovski et al. (2015). The authors used both the flood depth (total water level at a given point) and the flood extent to evaluate present-day and future flood hazards at coastal cities from Emilia-Romagna (Italy). An inter comparison of the above methods to assess the inundation caused by the Xynthia storm to La Faute-sur-Mer is provided by Breilh et al. (2013) and Vousdoukas et al. (2016). Furthermore, Vousdoukas et al. (2016) applied the above indicators to assess the flood hazard along the entire European coast. Poulter and Halpin (2008) used and improved the bathtub method by incorporating the hydrological connectivity between grid cells by considering that only cells that have a connection with the open sea or with nearby cells are considered flood-prone. Perini et al. (2016) used the tilted bathtub approach and the Cost Distance tool of ArcGIS to produce a least-path cost analysis and to remove isolated areas without hydrological connectivity in order to improve the final flood maps. 
Fig 3. Cross-shore and plan view representing the concept and application of the inundation indicators. White polygons represent the location of the hazard receptors (e.g. houses, hotels). FD - Flood depth; FE - Flood extent.

Erosion indicators events or storm groups effecting coastal areas, excluding continuous erosion caused by persistence of sediment scarcity. Storm-induced erosion can be observed as a vertical overall and definitive displacement of the shoreline since the coast can recover to its point (e.g. dune foot, dune crest, at the infrastructure) (Figure 4). The shoreline/berm 
the storm at a given coastal feature (Figure 4), and can be directly compared with occupation to assess vulnerability. The use of the shoreline/berm retreat versus the dune foot retreat as indicators depends very much on the exposed elements to be assessed. For coastal areas with infrastructure located on the beach berm or on the beach face (e.g. bars, amenities) the shoreline/berm retreat should be used, which can then be transformed (or not) into a remaining beach width or into a distance to occupation. For coastal areas where development and infrastructure (e.g. houses, roads) are located on the dune or at the hinterland, the dune foot retreat should be applied. This can also be transformed into a remaining distance to the developed area when necessary/applicable. The use of the shoreline/berm retreat versus the dune foot retreat also depends on the coastal morphology; at sandy coasts without a dune the shoreline/berm retreat should be used. The vertical erosion corresponds to the vertical difference between the original morphology and the computed/observed morphology during and after the storm (Figure 4). Vertical differences can result in potential damage for the existing development on the beach. This indicator can be equally used on the berm, dune or backbarrier, for any storm and given morphological characteristics, allowing the cross-shore determination and comparison of the vertical erosion indicator. The retreat/erosion indicators can be computed by using relatively simple analytical models, such as the convolution model (Kriebel and Dean, 1993), Larson's method (Larson et al., 2004), the erosion structural function (Mendoza and Jiménez, 2006), or the ShoreFor behaviour model (Davidson et al., 2013), among many others. These models use relatively simple analytical formulations that integrate driving mechanisms (such as wave height, storm duration and sea level) jointly with the morphological and sedimentological characteristics of the coastal area (e.g. dune 
height, berm width, beach slope or grain size) to determine coastal erosion (volume or retreat) induced by each storm. All the above methods deal with swash and collision conditions but not with overwash and inundation. For the later regimes, the erosion processes are different and generally more complex. Process-based models, like XBeach (Roelvink et al., 2009), can also be employed to determine the same indicators, for all regimes and with greater detail but requiring a higher level of computational complexity and available data for model calibration. Process-based models like XBeach reproduce the processes occurring at coastal areas during a storm, containing the essential physics of dune erosion, overwash, avalanching, swash, infragravity waves and wave groups (Roelvink et al., 2009). Finally, if LIDAR (Light Detection and Ranging) or similar resolution/quality data (e.g. from UAVs or satellite imagery) exists for preand post-storm conditions the erosion indicators can also be computed based on direct measurements (for example by comparing pre and post storm digital terrain models) and for all storm impact regimes following the method of Stockdon et al. (2007).

According to Ciavola et al. (2015) dune erosion volume, berm retreat or dune height reduction can be used directly or against thresholds to identify areas prone or resistant to erosion hazards. Nevertheless, the use of process-based erosion indicators is not widespread, with trend indicators such as shoreline position, high water line, vegetation line or scarp location (see Hanslow, 2007) being the most widely used. The sub-aerial beach and dune volume are also used as coastal indicators (Hanslow, 2007; Armaroli et al., 2012) but not necessarily as process-based indicators, with exceptions such as the use of the erosion resistance index by Judge et al. (2003), the eroded volume and the beach retreat (e.g. Mendoza and Jiménez, 2006), and the dune 
376 stability factor by Armaroli et al. (2012). Examples of use of process-based erosion indicators also include the distance between the dune and the shoreline or the 378 comparison between the momentary coastline position and a given landward 379 boundary, such as the dune foot (see Davidson et al., 2006).

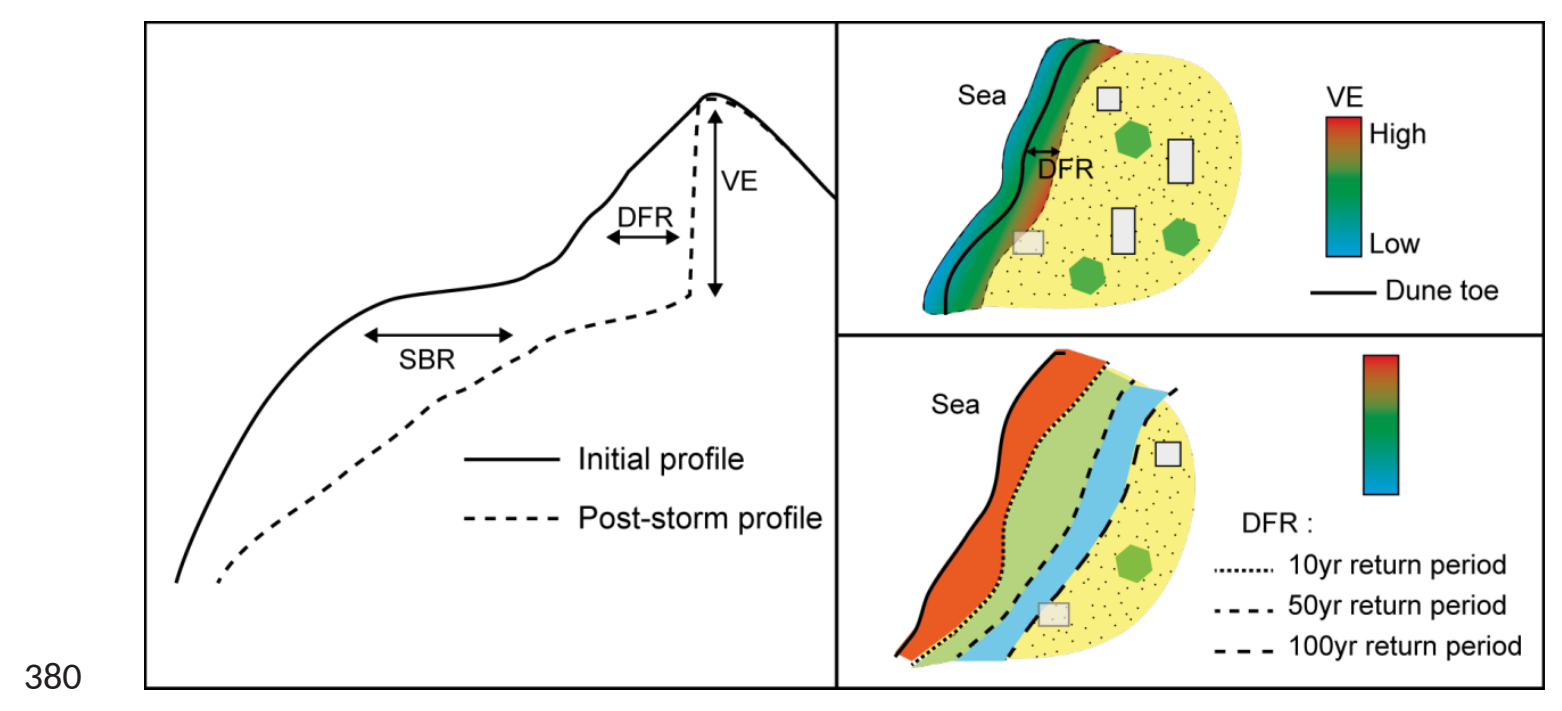

381 Fig 4. Cross-shore and plan view representing the concept and application of the 382 erosion indicators. White polygons represent the location of the hazard receptors (e.g. 383 houses, hotels). SBR - Shoreline/Berm retreat; DFR - Dune foot retreat; VE - Vertical erosion.

4. Summary of indicators and discussion of use

A synthesis of the reviewed and proposed indicators for three main analysed hazards (overwash, inundation and erosion), on sandy shores, can be found in Table I. The proposed process-based indicators are all simple in concept and refer to a measurable 390 distance, permitting a cartographic expression of the hazard (see figures 2 to 4). 391 Several indicators report a vertical difference to the initial topographic surface 
392 (overwash depth, overwash potential, flood depth, vertical erosion) representative of 393 an interaction between driving processes (e.g. water level, runup) and such surface (as 394 is the case for overwash depth, overwash potential and flood depth) or the result of 395 the morphodynamic process measured as a difference between pre and post-event 396 surfaces (vertical erosion). Others (overwash extent, flood extent, shoreline/berm 397 retreat, and dune foot retreat) register the cross-shore extent of the hazard. The 398 alongshore integration of both (vertical and horizontal indicators) allows, in most 399 cases, for an overall three-dimensional cartography of the hazard, including the 400 potentially affected areas and the vertical level of action. That is, for instance, the case 401 of the joint use of the overwash/flood depth and the associated extent. The vertical 402 erosion indicator, since it is immediately associated with an inland position, allows a 403 direct three-dimensional representation of the hazard when expressed alongshore.

404 The here-reviewed and proposed indicators can be applied on natural sandy (or 405 gravely) beaches with or without dune systems or backbarriers. Although the 406 indicators are not necessarily limited in their use, some of the proposed approaches 407 are, and they can only be applied to coastal areas with low morphological complexity.

408 This includes the case of the determination of the flood depth/extent by using a 409 bathtub (or tilted bathtub) approach. Most of the existing formulations and models are 410 also not completely adapted to heavily developed hinterlands (e.g. dominated by 411 impermeable surfaces) and will require some adaptation. Previous knowledge of the 412 dominant processes during storms will also help to correctly select the methods and 413 indicators to use in the most cost-effective way. 
414 A direct comparison on the applicability of selected (based on the works of Carapuço

415 et al., 2016 and Nguyen et al., 2016) geo- and driver- based indicators against the

416 proposed process-based indicators is expressed at Table II. Most geo- and driver-based

417 indicators are easier to obtain since they can be directly extracted from existing 418 cartography or field measurements (geoindicators) and from instrumental 419 measurements or hindcast predictions (driver-based indicators) often available on-line.

420 They are commonly converted into several simple semi-quantitative values (e.g. from 1

421 to 5) that are added (quantified) alongshore to permit a representation of the hazard,

422 making them simple to use even for non-experts. They are therefore still used as a

423 simple methodology to classify the coast according to its vulnerability (e.g. Jiménez et

424 al., 2016). They do not, however, account for the acting processes and can therefore

425 affect the final results as observed by Judge et al. (2003) when considering the crest

426 height as a predictor of dune vulnerability. Process-based indicators require both geo-

427 and driver-based information and the additional use of formulations/models, to obtain

428 a final value. If using return periods, a statistical analysis (for either the event or

429 response approach) is also required. This implies, from the users, a higher expertise on

430 coastal dynamics, including the perception of the physical processes acting in coastal

431 areas and responsible for hazards. This reduces the applicability of process-based

432 indicators to users with sufficient background on coastal dynamics. Process-based

433 indicators have, however, several advantages that will, most probably, increase their

434 future use. Most indicators have the possibility of including both detailed longshore

435 variability and cross-shore expression of the hazard, while driver-based indicators have

436 a reduced representativeness of the longshore variability, mainly if wave propagation

437 models are not used. Most used geo and driver-based indicators are also not able to 
438 include the cross-shore expression of the hazard (with the exception of the erosion 439 rate).

440 Geo- and driver-based indicators when used alone are often site-specific and hardly 441 comparable between coastal areas. Process-based indicators present an outcome that 442 can be easily compared among sites. For instance, the vertical expression of a hazard 443 (e.g. flood depth or overwash depth) can be compared between coastal regions with 444 similar settings and a higher value of the indicator will represent a potentially higher 445 hazard. That is not the case for driver-based indicators, for instance. A higher wave 446 height or water level cannot be compared between coastal areas since the hazard will 447 depend on the relationship with the coastal elevation. A lower value of a driver-based 448 indicator can be responsible for a higher hazard if the coastal elevation is low, and the 449 opposite is also valid. This prevents the compared use of geo- and driver-based 450 indicators to assess the hazard for distinct coastal areas. The extensive use of process451 based indicators, for different coastal regions will allow, in the future, the 452 development of hazard levels/scales that can be internationally adopted. Since 453 process-based indicators can be associated with a given probability of occurrence and 454 can be directly compared between coastal regions, they can also be used to rank the 455 hazard intensity for vast coastal areas, for equal return periods. It must however be 456 stressed that, for the moment, no universal application of indicators exists and that 457 there are no internationally widely accepted intervals to classify each indicator 458 according to the potential hazard. This is still work to be performed, to be based on the 459 lessons learned from the application of process-based indicators at a large-scale. 
460 The here proposed process-based indicators do not integrate feedback mechanisms

461 resulting from the interaction between morphology and forcing agents (e.g. waves,

462 currents). That is also the case for geoindicators and for indicators solely based on

463 driving mechanisms. The hazard and consequent risk can change as a result of

464 feedback mechanisms. For instance, the lowering of a dune by overwash will increase

465 the overwash potential and the overwash depth, leading to an increase in the hazard

466 when compared with the initial (and considered) situation/morphology. The feedback

467 mechanism can occur differently alongshore, as a function of the nearshore, shoreface

468 and dune morphologies. In cases where feedback mechanisms may be highly relevant,

469 these (and other indexes) may not fully reflect the impacts associated with a given

470 event. In those cases only process-based models with high resolution topo-

471 bathymetric grids, after validation and calibration, may be helpful to better understand

472 the hazard in coastal areas. It must be also kept in mind that the indicators must

473 remain simple in concept and application to ensure their use by most coastal

474 managers. Highly complex indicators requiring extreme computational effort and a

475 high degree of specialization will probably fail to be widely applied by most coastal 476 end-users, including managers.

5. Conclusions, limitations and future improvements

479 The current use of process-based indicators is still on its infancy, being necessary to 480 establish a set of the most relevant indicators that can better express potential hazards 481 at sandy (and gravelly) shores: - Overwash: overwash depth, potential and extent; 
- Inundation: flood depth and extent;

- Erosion: shoreline/berm and dune foot retreat, and vertical erosion.

The future use of process-based indicators to quantify coastal hazards is recommended, mainly when compared to the most classical and commonly used geoand driver-based indicators, since they allow:

a) better quantification of the hazard by representing the interaction between forcing mechanisms and morphology;

b) better expression of the alongshore and cross-shore (extent) variability of the hazard, including its three-dimensional representation (longshore, cross-shore and vertical); and

c) comparison between coastal areas.

The development of the process-based indicators' potential will rely on their generalised use in the future. Only an increase in their use will allow the definition of common hazard levels for distinct coastal regions and a large-scale application to vast areas (e.g. at pan-European level). A few limitations still exist that prevent the wider use of these indicators. These include:

i) limited available quality data for several regions, regarding either morphologic and hydrodynamic parameters, which is particularly relevant when long-term time-series (e.g. wave characteristics) are needed to better define return periods;

ii) restricted current use of formulations and models by end-users and namely coastal managers; 
iii) reduced possibility of integrating feedback mechanisms, with the exception of the most complex process-based models.

507 The first limitation will be solved (with time) by the ongoing and increasing 508 improvement on data access (and quality) worldwide, including on-line access to 509 coastal morphology and wave/water level series. To obviate the second limitation an 510 improvement will be needed on the transfer of knowledge from the coastal scientific

511 community towards coastal end-users. The third limitation will be solved by integrating

512 process-based models into user-friendly frameworks for generalised use. The 513 improved and generalised use of process-based indicators will provide coastal 514 managers with a highly relevant tool to evaluate coastal hazards and risks and, 515 therefore, to better establish and implement disaster risk reduction in the future, in 516 the most cost-effective way.

Acknowledgments

519 This work was supported by the European Community's 7th Framework Programme 520 through the grant to RISC-KIT ("Resilience-increasing Strategies for Coasts - Toolkit"), 521 contract no. 603458 , and by contributions by the partner institutes. Susana Costas 522 research is funded through the "FCT Investigator" program (ref. IF/01047/2014). This 523 work was also supported by the Portuguese Science Foundation (FCT) through the 524 grant UID/MAR/00350/2013 attributed to CIMA/University of Algarve 
527 Almeida, L.P., Ferreira, O., Taborda, R., 2011. Geoprocessing tool to model beach

528 erosion due to storms: application to Faro beach (Portugal). Journal of Coastal

529 Research, SI 64, 1830-1834.

530 Almeida L. P., Vousdoukas M. V., Ferreira O., Rodrigues, B.A., Matias, A., 2012.

531 Thresholds for storm impacts on an exposed sandy coastal area in southern Portugal,

532 Geomorphology, 143, 3-12. DOI: 10.1016/j.geomorph.2011.04.047

533 Armaroli, C., Ciavola, P., Perini, L., Calabrese, L., Lorito, S., Valentini, A., Masina, M., 534 2012. Critical storm thresholds for significant morphological changes and damage 535 along the Emilia-Romagna coastline, Italy. Geomorphology, 143, 34-51. 536 DOI: 10.1016/j.geomorph.2011.09.006

537 Battjes, J.A., 1974. Surf similarity. Coastal Engineering'74, 446-480.

538 Bennington, B. and Farmer, E.C., 2015. Learning from the impacts of Superstorm Sandy.

539 Ed. J. Bret Bennington and E.Christa Farmer. Academic Press. Elsevier, 123 p.

540 Bertin, X., Bruneau, N., Breilh, J.F., Fortunato, A.B., Karpytchev, M., 2012. Importance 541 of wave age and resonance in storm surges: The case Xynthia, Bay of Biscay. Ocean 542 Modelling, 42, 16-30. DOI: 10.1016/j.ocemod.2011.11.001

543 Bosom, E. and Jiménez, J.A., 2011. Probabilistic coastal vulnerability assessment to 544 storms at regional scale - application to Catalan beaches (NW Mediterranean). Natural 545 Hazards and Earth System Sciences, 11, 475-484. DOI: 10.5194/nhess-11-475-2011

546 Breilh, J.F., Chaumillon, E., Bertin, X., Gravelle, M., 2013. Assessment of static flood 547 modeling techniques: application to contrasting marshes flooded during Xynthia 
Bush, D.M., Neal, W.J., Young, R.S., Pilkey, O.H., 1999. Utilization of geoindicators for

551 rapid assessment of coastal-hazard risk and mitigation. Ocean and Coastal Management, 42, 647-670. DOI: 10.1016/S0964-5691(99)00027-7

553 Callaghan, D.P., Nielsen, P., Short, A., Ranasinghe, R., 2008. Statistical simulation of

554 wave climate and extreme beach erosion. Coastal Engineering, 55(5), 375-390.

555 DOI:10.1016/j.coastaleng.2007.12.003

556 Carapuço, M.M., Taborda, R., Silveira, T.M., Psuty, N.P., Andrade, C., Freitas, M.C., 557 2016. Coastal geoindicators: Towards the establishment of a common framework for 558 sandy coastal environments. Earth-Science Reviews, 154, 183-190. DOI: 10.1016/j.earscirev.2016.01.002

560 Castelle, B., Marieu, V., Bujan, S., Splinter, K.D., Robinet, A., Senechal, N., Ferreira, S., 561 2015. Impact of the winter 2013-2014 series of severe Western Europe storms on a 562 double-barred sandy coast: Beach and dune erosion and megacusp embayments.

563 Geomorphology, 238, 135-148. DOI: 10.1016/j.geomorph.2015.03.006

564 Christie, E.K., Spencer, T., Owen, D., Mclvor, A.L., Möller, I., Viavattene, C., 2017. 565 Regional coastal flood risk assessment for a tidally dominant, natural coastal setting:

566 North Norfolk, southern North Sea. Coastal Engineering, in press. DOI: 567 10.1016/j.coastaleng.2017.05.003 
568 Ciavola, P., Ferreira, O., van Dongeren, A., de Vries, J., Armaroli, C., Harley, M., 2015.

569 Prediction of storms impacts on beach and dune systems. In: Hydrometeorological

570 Hazards: Interfacing Science and Policy. Ed: Philippe Quevauviller, John Wiley \& Sons.

571 Clay, P.M., Colburn, L.L., Seara, T., 2016. Social bonds and recovery: An analysis of

572 Hurricane Sandy in the first year after landfall. Marine Policy, 74, 334-340. DOI:

573 10.1016/j.marpol.2016.04.049

574 Davidson, M.A., Aarninkhof, S., van Koningsveld, M., Holman, R.A., 2006. Developing 575 coastal video monitoring systems in support of coastal zone management. Journal of 576 Coastal Research, SI 39, 49-56.

577 Davidson, M.A., van Koningsveld, M., de Kruif, A., Rawson, J., Holman, R., Lamberti, A., 578 Medina, R., Kroon, A., Aarninkhof, S., 2007. The CoastView project: Developing video579 derived Coastal State Indicators in support of coastal zone management. Coastal 580 Engineering, 54, 463-475. DOI: 10.1016/j.coastaleng.2007.01.007

581 Davidson, M.A., Splinter, K.D., Turner, I.L., 2013. A simple equilibrium model for 582 predicting shoreline change. Coastal Engineering, 73, 191-202. DOI: $583 \quad$ 10.1016/j.coastaleng.2012.11.002

584 De Roo, A.P.J., Wesseling, C.G., van Deursen, W.P.A., 2000. Physically base driver basin 585 modelling within a GIS: the LISFLOOD model. Hydrological Processes, 14, 1981-1992. 586 DOI: 10.1002/1099-1085(20000815/30)14:11/12<1981::AID-HYP49>3.0.CO;2-F

587 Del Río, L., Plomaritis, T.A., Benavente, J., Valladares, M., Ribera, P., 2012. Thresholds 588 for storm impacts along European coastlines. Geomorphology, 143-144, 13-23. DOI:10.1016/j.geomorph.2011.04.048 
590 Divory, D. and McDougal, W.G., 2006. Response-based coastal flood analysis.

591 Proceedings of the $30^{\text {th }}$ International Conference on Coastal Engineering, 5291-5301, 592 ASCE.

593 Donnelly, C., 2008. Coastal Overwash: Processes and Modelling. PhD Thesis. Lund 594 University, Sweden, 53 pp.

595 Dottori, F., Martina, M.L.V., Figueiredo, R., 2016. A methodology for flood 596 susceptibility and vulnerability analysis in complex flood scenarios. Journal of Flood 597 Risk Management, DOI: 10.1111/jfr3.12234

598 Durán, R., Guillén, J., Ruiz, A., Jiménez, J.A., Sagristà, E., 2016. Morphological changes, 599 beach inundation and overwash caused by an extreme storm on a low-lying embayed 600 beach bounded by a dune system (NW Mediterranean). Geomorphology, 274, 129-142. 601 DOI: 10.1016/j.geomorph.2016.09.012

602 Ferreira, O., Viavattene, C., Jiménez, J., Bole, A., Plomaritis, T., Costas, S., Smets, S., 603 2016. CRAF Phase 1, a framework to identify coastal hotspots to storm impacts. E3S 604 Web Conf. 7, 11008 (FLOODrisk 2016: 3rd European Conference on Flood Risk 605 Management).

606 Fortunato, A.B., Li, K., Bertin, X., Rodrigues, M., Miguez, B.M., 2016. Determination of 607 extreme sea levels along the Iberian Atlantic coast. Ocean Engineering, 111, 471-482. 608 DOI:10.1016/j.oceaneng.2015.11.031

609 Garcia, T., Ferreira, O., Matias, A., Dias, J.A., 2010. Overwash vulnerability assessment 610 based on long-term washover evolution. Natural Hazards, 54, 225-244. DOI: 
612 Gouldy, B. and Samuels., P, 2005. Language of Risk - Project Definitions. Report: T32-

613 04-01.Floodsite Project. Available at www.floodsite.net

614 Guza, R.T and Inman, D.I., 1975. Edge waves and beach cusps. Journal of Geophysical 615 Research, 80, 1328-1342. DOI: 10.1029/JC080i021p02997

616 Haerens, P., Bolle, A., Trouw, K., Houthuys, R., 2012. Definition of storm thresholds for 617 significant morphological change of the sandy beaches along the Belgian coastline. 618 Geomorphology, 143-144, 104-117. DOI:10.1016/j.geomorph.2011.09.015

619 Hanslow, D.J., 2007. Beach erosion trend measurement: A comparison of trend 620 indicators. Journal of Coastal Research, SI 50, 588-593.

621 Hinkel, J., Lincke, D., Vafeidis, A.T., Perrette, M., Nicholls, R.J., Tol, R.S.J., Marzeion, B., 622 Fettweis, X., lonescu, C., Levermann, A., 2014. Coastal flood damage and adaptation 623 costs under 21st century sea-level rise, Proceedings of the National Academy of 624 Sciences of the United States of America, 111, 3292-3297. doi: $625 \quad 10.1073 /$ pnas.1222469111

626 Holman, R.A., 1986. Extreme value statistics for wave run-up on a natural beach.

627 Coastal Engineering, 9, 527-544. DOI: 10.1016/0378-3839(86)90002-5

628 Jiménez, A.C., Ávila, J.I.E, Lacouture, M.M.V., Casarín, R., 2016. Classification of beach 629 erosion vulnerability on the Yucatan Coast. Coastal Management, 44, 333-349. DOI: $630 \quad 10.1080 / 08920753.2016 .1155038$

631 Judge, E.K., Overton, M.F., Fisher, J.S., 2003. Vulnerability indicators for coastal dunes. 632 Journal of Waterway, Port, Coastal and Ocean Engineering, 129, 270-278. DOI: 10.1061/(ASCE)0733-950X(2003)129:6(270) 
634 Kantha, L., 2013. Classification of hurricanes: Lessons from Katrina, Ike, Irene, Isaac and

635 Sandy. Ocean Engineering, 70, 124-128. DOI: 10.1016/j.oceaneng.2013.06.007

636 Kindsvater, C. and Carter, R., 1957. Discharge characteristics of rectangular thin-plate 637 weirs, Journal of the Hydraulics Division, ASCE, 83, 1453/1-1453/36.

638 Kriebel, D. and Dean, R.G., 1993. Convolution model for time-dependent beach-profile 639 response. Journal of Waterway, Port, Coastal and Ocean Engineering, 119, 204-226. 640 DOI: 10.1061/(ASCE)0733-950X(1993)119:2(204)

641 Larson, M., Erikson, L., Hanson, H., 2004. An analytical model to predict dune erosion 642 due to wave impact. Coastal Engineering, 51, 675-696. DOI: $643 \quad 10.1016 / j . c o a s t a l e n g .2004 .07 .003$

644 Link, L.E., 2010. The anatomy of a disaster, an overview of Hurricane Katrina and New 645 Orleans. Ocean Engineering, 37, 4-12. DOI: 10-1016/j.oceaneng.2009.09.002

646 Long, J.W., de Bakker, A.T.M., Plant, N.G., 2014. Scaling coastal dune elevation changes 647 across storm-impact regimes. Geophysical Research Letters, 41. 648 DOI:10.1002/2014GL059616

649 Masselink, G. and Hegge, B., 1995. Morphodynamics of meso and macrotidal beaches: 650 examples from central Queensland, Australia. Marine Geology, 129, 1-23. DOI: $651 \quad 10.1016 / 0025-3227(95) 00104-2$

652 Masselink, G., Scott, T., Poate, T., Russell, P., Davidson, M., Conley, D., 2016a. The 653 extreme 2013/2014 winter storms: hydrodynamic forcing and coastal response along 654 the southwest coast of England. Earth Surface Processes and Landforms, 41, 378-391. DOI: 10.1002/esp.3836 
656 Masselink, G., Castelle, B., Scott, T., Dodet, G., Suanez, S., Jackson, D., Floc'h, F., 2016b.

657 Extreme wave activity during 2013/2014 winter and morphological impacts along the

658 Atlantic coast of Europe. Geophysical Research Letters, 43, 2135-2143. DOI:

$65910.1002 / 2015 G L 067492$

660 Matias, A., Masselink, G., Turner, I., Williams, J.J., Ferreira, Ó., 2011. Detailed analysis

661 of overwash on gravel barriers. Journal of Coastal Research, SI 64, 10-14.

662 Matias, A., Williams, J., Masselink, G., Ferreira, O., 2012. Overwash threshold for gravel 663 barriers. Coastal Engineering, 63, 48-61. DOI: 10.1016/j.coastaleng.2011.12.006

664 Matias, A., Blenkinsopp, C.E., Masselink, G., 2014. Detailed investigation of overwash on a gravel barrier. Marine Geology. 350, 27-38. DOI: 10.1016/j.margeo.2014.01.009

666 Matias, A., Masselink, G., Castelle, B., Blenkinsopp, C.E., Kroon, A., 2016. 667 Measurements of morphodynamic and hydrodynamic overwash processes in a large668 scale wave flume. Coastal Engineering, 113, 33-46. DOI: 669 10.1016/j.coastaleng.2015.08.005

670 Matias, A.. and Masselink, G., 2017. Overwash processes: lessons from fieldwork and 671 laboratory experiments. In: Coastal Storms: Processes and Impacts. Ed: Paolo Ciavola 672 and Giovanni Coco. John Wiley \& Sons.

673 Mendoza, E.T. and Jiménez, J.A., 2006. Storm-induced beach erosion potential on the 674 Catalonian coast. Journal of Coastal Research, SI 48, 81-88.

675 Neumann, B., Vafeidis, A.T., Zimmermann, J., Nicholls, R.J., 2015. Future Coastal 676 Population Growth and Exposure to Sea-Level Rise and Coastal Flooding - A Global 677 Assessment. PLoS ONE, 10, e0118571. 
678 Nguyen, T.T.X., Bonetti, J., Rogers, K., Woodroffe, C.D., 2016. Indicator-based

679 assessment of climate-change impacts on coasts: A review of concepts, methodological

680 approaches and vulnerability indices. Ocean and Coastal Management, 123, 18-43.

681 DOI: 10.1016/j.ocecoaman.2015.11.022

682 Perini, L., Calabrese, L., Salerno, G., Ciavola, P., Armaroli, C., 2016. Evaluation of coastal

683 vulnerability to flooding: comparison of two different methodologies adopted by the

684 Emilia-Romagna region (Italy). Natural Hazards and Earth Systems Science, 16, 181-

685

194. DOI: $10.5194 /$ nhess-16-181-2016

686 Poelhekke, L., Jäger, W.S, van Dongeren, A., Plomaritis, T.A., McCall, R., Ferreira, O.,

687 2016. Predicting coastal hazards for sandy coasts with a Bayesian Network. Coastal

688 Engineering, 118, 21-34. DOI: 10.1016/j.coastaleng.2016.08.011

689 Poulter, B. and Halpin, P. N., 2008. Raster modelling of coastal flooding from sea-level 690 rise. International Journal of Geographical Information Science, 22, 167-182. 691 DOI: 10.1080/13658810701371858

692 Ramirez, J.A., Lichter, M., Coulthard, T.J., Skinner, C., 2016. Hyperresolution mapping 693 of regional storm surge and tide flooding: comparison of static and dynamic models, 694 Natural Hazards, 82, 571-590. DOI: 10.1007/s11069-016-2198-z

695 Rodrigues, B. A., Matias, A., Ferreira, O., 2012. Overwash hazard assessment. 696 Geologica Acta, 10, 427-437. DOI: 10.1344/105.000001743

697 Roelvink, D., Reniers, A., van Dongeren, A.P., de Vries, J.V.T., McCall, R., Lescinski, J., 698 2009. Modelling storm impacts on beaches, dunes and barrier islands. Coastal 699 Engineering, 56, 1133-1152. DOI: 10.1016/j.coastaleng.2009.08.006 
702 Sánchez-Arcilla, A., Jiménez, J.A., Peña, C., 2009. Wave-induced morphodynamic risks.

703 Characterization of extremes. Coastal Dynamics 2009, World Scientific (CD), paper 127.

704 Sekovski, I., Armaroli, C., Calabrese, L., Mancini, F., Stecchi, F., Perini, L., 2015. Coupling

705 scenarios of urban growth and flood hazards along the Emilia-Romagna coast (Italy).

706 Natural Hazards and Earth System Sciences, 15, 2331-2346, DOI: 10.5194/nhess-15-

$707 \quad 2331-2015$

708 Silveira, T.M., Taborda, R., Carapuço, M.M., Andrade, C., Freitas, M.C., Duarte, J.F., 709 Psuty, N.P., 2016. Assessing the extreme overwash regime along an embayed urban 710 beach. Geomorphology, 274, 64-77. DOI: 10.1016/j.geomorph.2016.09.007

711 Smallegan, S.M., Irish, J.L., van Dongeren, A.R., den Bieman, J.P., 2016. Morphological 712 response of a sandy barrier island with a buried seawall during Hurricane Sandy.

713 Coastal Engineering, 110, 102-110. DOI: 10.1016/j.coastaleng.2016.01.005

714 Stockdon, H.F., Holman, R.A., Howd, P.A., and Sallenger, A.H., 2006. Empirical 715 parameterization of setup, swash and run-up. Coastal Engineering, 53, 573-588.

716 DOI: 10.1016/j.coastaleng.2005.12.005

717 Stockdon, H.F., Sallenger Jr, A.H., Holman, R.A., Howd, P.A., 2007. A simple model for 718 the spatially-variable coastal response to hurricanes. Marine Geology, 238, 1-20.

719 DOI:10.1016/j.margeo.2006.11.004 
720 Trifonova, E.V., Valchev, N.N., Andreeva, N.K., Eftimova, P.T., 2012. Critical storm

721 thresholds for morphological changes in the western Black Sea coastal zone.

722 Geomorphology, 143-144, 81-94. DOI:10.1016/j.geomorph.2011.07.036

723 Valchev, N., Andreeva, N., Eftimova, P., Prodanov, B., Kotsev, I., 2016. Assessment of

724 vulnerability to storm induced flood hazard along diverse coastline settings. E3S Web

725 Conference 7, 10002. FLOODrisk 2016 - 3rd European Conference on Flood Risk

726 Management.

727 van Koningsveld, M., Davidson, M.A., Huntley, D.A., 2005. Matching science with coastal management needs: The search for appropriate coastal state indicators. Journal of Coastal Research, 21, 399-411. DOI: 10.2112/03-0076.1

730 van Verseveld, H.C.W., van Dongeren, A.R., Plant, N.G., Jäger, W.S., den Heijer, C., 2015. Modelling multi-hazard hurricane damages on an urbanized coast with a

732 Bayesian Network approach. Coastal Engineering, 103, 1-14. DOI: 10.1016/j.coastaleng.2015.05.006

734 Vousdoukas, M.I., Voukouvalas, E., Mentaschi, L., Dottori F., Giardino, A., Bouziotas, D.,

735 Bianchi, A., Salamon, P., Feyen, L., 2016. Developments in large-scale coastal flood 736 hazard mapping. Natural Hazards Earth System Science, 16, 1841-1853. DOI: 737 10.5194/nhess-2016-124.

738 Williams, J.J., Masselink, G., Buscombe, D., Turner, I., Matias, A., Ferreira, Ó., Metje, N., 739 Coates, L., Chapman, D., Bradbury, A., Albers, A., Pan, S., 2009. BARDEX (Barrier 740 Dynamics Experiment): taking the beach into the laboratory. Journal of Coastal $741 \quad$ Research, SI 56: 158-162. 
742 Wright, L.D. and Short, A.D., 1984. Morphodynamic variability of surf zones and

743 beaches: a synthesis. Marine Geology, 56, 93-118. DOI: 10.1016/0025-3227(84)90008- 


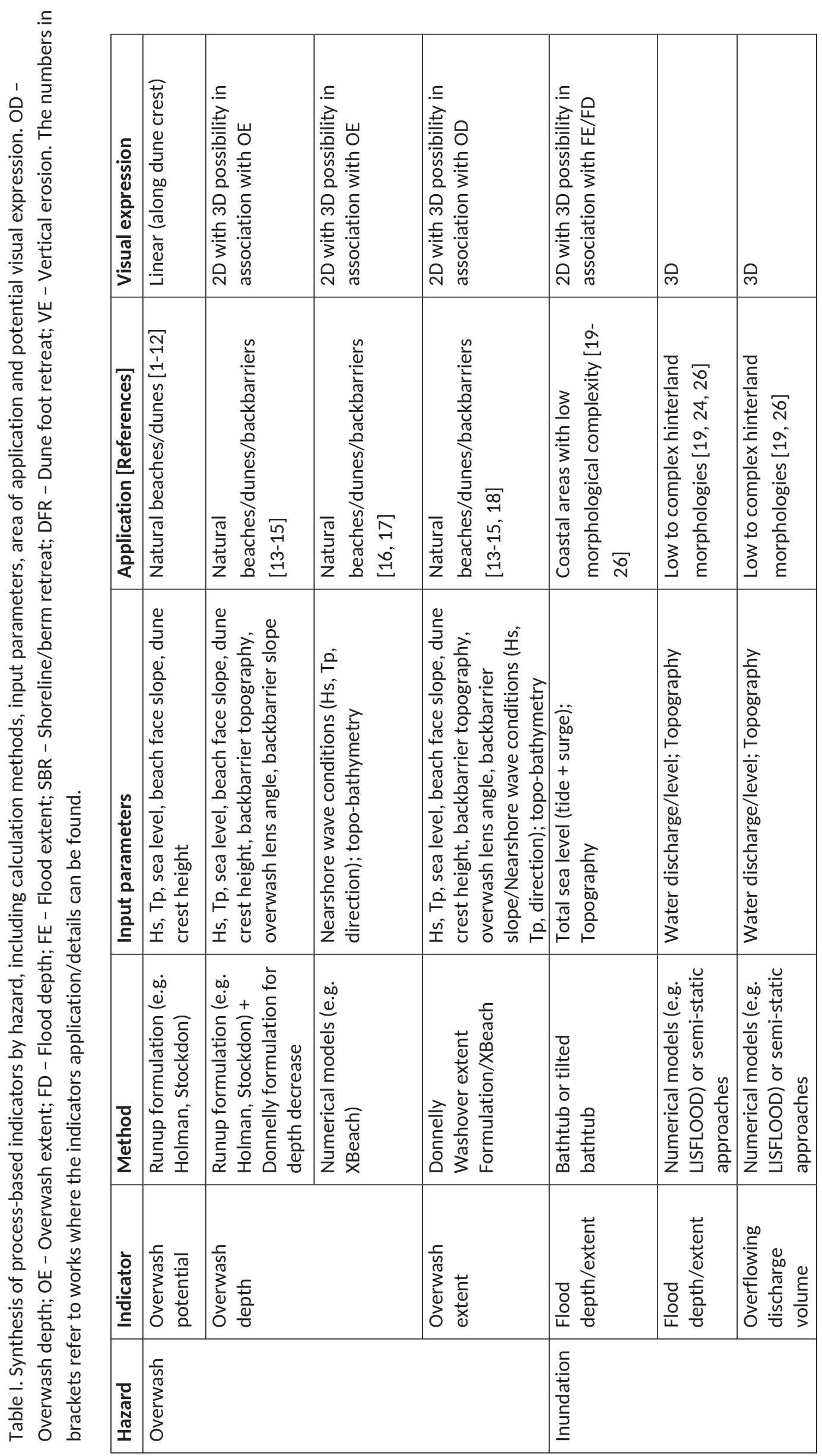




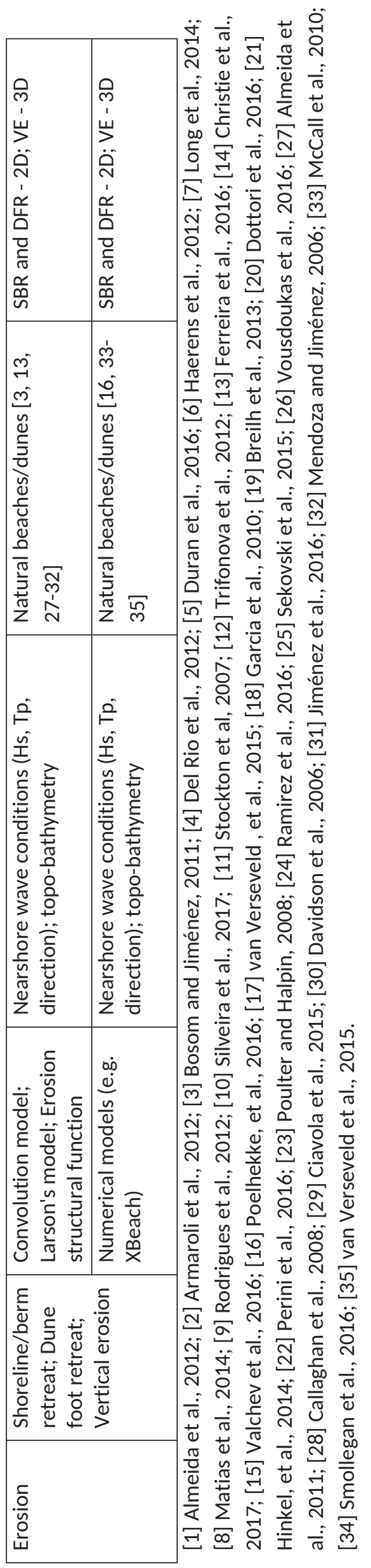




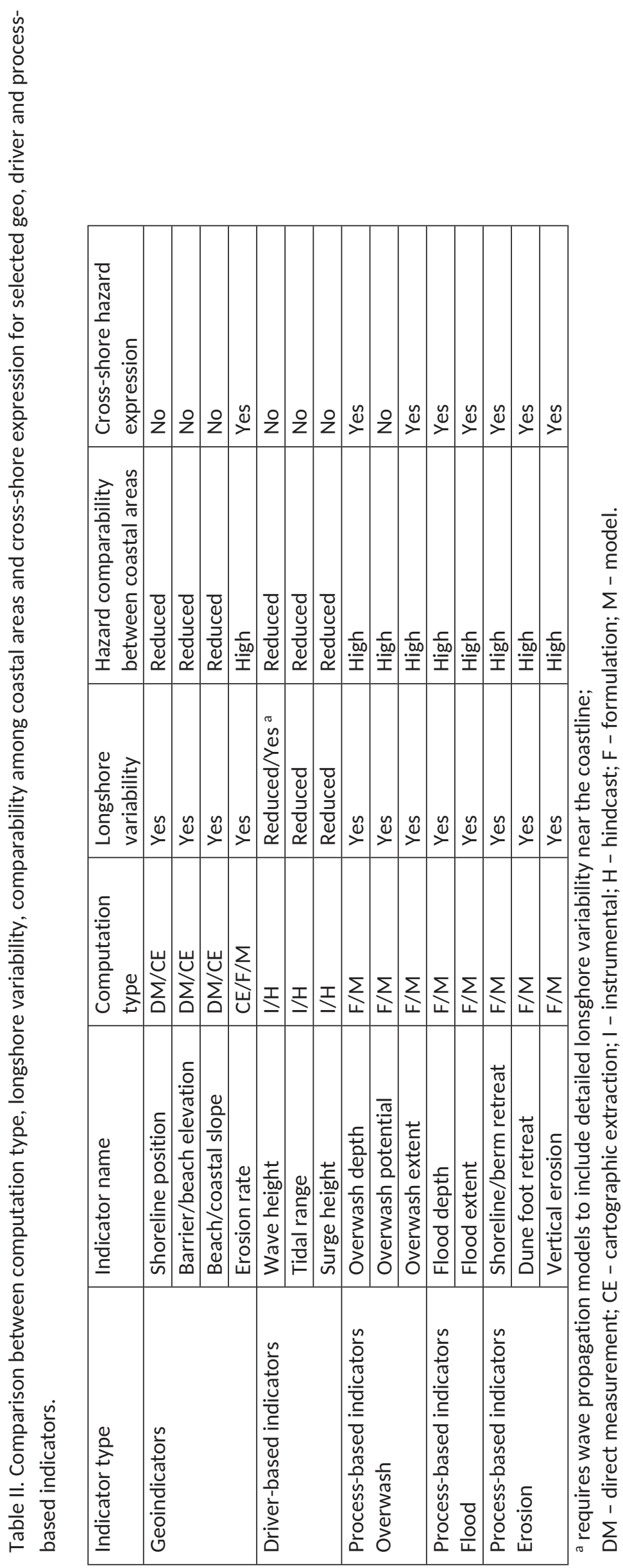

